\title{
IAMJ
}

INTERNATIONAL

AYURVEDIC

MEDICAL JOURNAL

ISSN: 2320-5091

Impact Factor: 6.719

\section{CONCEPT OF PATHYA AND APATHYA WITH SPECIAL REFERENCE TO CURD - A REVIEW}

\section{Priyanka B.V. ${ }^{1}$, Abhijith Joshi ${ }^{2}$, Manjunatha Adiga ${ }^{3}$}

${ }^{1}$ Associate Professor, Department of Ayurveda Samhita and Siddhanta, SKAMCH \& RC, Bangalore, Karnataka, India

${ }^{2}$ Professor \& HOD, Department of Samhita, TMV, Pune, Maharashtra, India

${ }^{3}$ Professor, Department of Kayachikitsa, SKAMCH \& RC, Bangalore, Karnataka, India

Corresponding Author: priya94814@gmail.com

https://doi.org/10.46607/iamj2609052021

(Published Online: May 2021)

Open Access

(C) International Ayurvedic Medical Journal, India 2021

Article Received:29/04/2021 - Peer Reviewed:29/04/2021 - Accepted for Publication:07/05/2021

Check for updates

\section{ABSTRACT}

The activities and the various food substances that are conducive to the Srotas (channels of the body) and mind are regarded as Pathya and those that are not conducive are regarded as Apathya. Pathya is also considered as synonymous to Chikitsa (treatment) according to Acharya Charaka. Other synonyms of Pathya are Satmya (habit) ,Swastha hitakara (Good for Health), Upshaya (palliative), Swavastha Paripaalaka (Maintains Health), Hita Ahara (Wholesome food), Swasthaaurjaskara (Promote health status), Sharmakara (establish Health), Dhatu Avirodhi (Not against body tissue) and Dhatu Saamyakara (Establish normalcy of body tissue). Pathya word is indicative for both food and activity.

Dadhi (Curd) is considered as both Pathya and Apathya. Dadhi belongs to Amla Skanda (group of sour drugs) and it is one among the Vicitra Pratyarabdha Dravya (substances which does not act as per Rasa Panchaka); as these Dravyas are having the capability of producing both positive and negative impact on health.

Dadhi is Pathya in conditions like anorexia, intermittent fever, diarrhea, emaciation, rhinitis, Dry cough, Irritable bowel syndrome and hemorrhoids. Dadhi is indicated in intermittent fever, where pathogenesis occurs due to- 
Vata, Kapha as alone or Vatakapha. Dadhi is Apathya in Kustha, Visarpa, Prameha etc. In this paper an attempt is made to understand the concept of Pathya and Apathy by considering diet as curd.

Keywords: Dadhi, Curd, Ayurveda, Pathya, Apathya.

\section{INTRODUCTION}

Pathya is one which is not harmful to patha or the srotas or channels and which is pleasent for Mana (mind). As per Acharya Chakrapani Patha is srotas, according to Acharya Ganghadhara channels which carries Vata, Pitta, kapha, Dhatu. It includes not only the entity which are carried by Srotas, also includes the Dhatu which under go transformation, there by whole body component can be included. Here the word "Manaha priya" i.e pleasent for mind indicates abour desire of intake of food as per Acharya Chakrapani, as per Acharya Ganghadhara the food which provides Sukha Anubhava (comfortable feeling) to mind. For a successful treatment, Pathya is very much essential. Similarly, Apathya can acts as cause for the disease. Food can be Pathya or Apathya depends on Matra i.e. quantity. By the influence of Matradi even Pathya can behave into Apathya \& vis versa.

The references about Pathya and Apathya are present in Veda, for instance according to the Rigveda, Soma is the functional part of wholesome food which is a powerful medicine for all diseases. Wholesome food acts as a medicine and it should be strictly followed ${ }^{1}$. In Yajurveda, Masha (Phaseolus moongo Linn.),Tila (Sesamum indicum Linn.), Mudga (Phaseolus radiatus Linn.), Priyangu (Setaria italic Beauv.), Shyamaka (Echino chloafrumentacea), Neevara (Hygroryza aristata Nees.), Godhuma (Triticum sativum Lam.), Masoora (Lens culinaris Medic.) etc are considered as Pathya.

Yajurveda states that water, food, air etc when purified by Yajna Karma acts as medicine ${ }^{2}$.

Atharveda states that a person who maintains Agni (fire), Jala (water), Vayu(air) and Prithavi (earth)by wholesome food and celibacy becomes energetic and healthy. He progresses towards the transcendent state attained as a result of being released from the cycle of rebirth $^{2.1}$. In Atharveda, some cereals like Virihi (Ory- za sativa Linn.), Yava (Hordeum vulgare Linn.), Tila (Sesamum indicumLinn.), Masoora (Lens culinaris Medic.), Masha (Phaseolus moongo Linn.) etc. have been described ${ }^{3}$.

Acharya Kashyapa explored the medicinal potential of Aahara (food) along with its prophylactic value of maintaining health. Kashyapa stated that modified \& specific food is the best medicine. No drug can match the benefits of food in diseased state. Only wholesome food can keep a person healthy. ${ }^{4}$

Acharya Harita stated the importance of Pathya (wholesome) and Apathya (unwholesome)by stating that if person ignores the concept of Pathya Apathya (unwholesome), illness will never leave the body. Hence one should use Pathya (wholesome) according to his/her physical and pathological condition regularly. Even in the absence of medicine, if patient takes only Pathya (whole some) according to disease he will become healthy, but even if patient takes more and regular medicine and avoid Pathya Ahara prescribed by physician he will neverbecomehealthy. ${ }^{5}$

Yogaratnakara, said that for the treatment of diseases three important factors like etiology, medicine properties and Pathya (wholesome) should be studied thoroughly before starting the treatment. Judicious planning of treatment by proper understanding of these three factors always yields a successful eradication of disease. Yogaratnakara uses the metaphor of Ankura (seedling) for progressive form of disease. This Ankura (seedling) will dry and be destroyed if it is not nourished by water; similarly, disease will be destroyed if a patient does not consume Apathya Ahara (unwholesome food) ${ }^{6}$.

Vaidya Lolimbraja indicated the importance of Pathya Aahara (wholesome food) by stating that if a patient intakes wholesome food then there is no need of medicine and if a patient continuously consumes unwhole- 
some food then also there is no need of medicine. In the latter case, medicine will not be effective.

Bhela Samhita also explains about merits of Pathya and demerits of Apathya in the Sutrasthana. Pathya Ahara nourishes all Dhatus (body elements) and Srotras (channels of circulation) leading to complete nutrition of body. Pathya Ahara also helps to detoxify the body by getting rid of vitiated Dosha. Contrary to this, Apathya Ahara helps in vitiation of Vata, Doshas etc. Hence for the maintenance of health and treating diseases Pathya Ahara should be consumed. ${ }^{7}$ On reviewing the Aharas, acharya charaka ${ }^{8}$ mentions that Shashtika, Shali, Yava, Mudga, Saindhava, Amalaka, rain water, ghee, meat of animals of aired climate, honey, and he also mentions Agrya of each Aharavargas which can also can be considered as Pathya'. The reference of Dadhi is evident in Vedic literature as one of the ingredients in Homa, Havana, individually or as one among Pancagavya ${ }^{10}$. It is an adjuvant to juice of Soma which is offered to lord Indra, Varuna and Vayu for their drinking and sacrificing to Yajna. The term used in Rigveda for Dadhi is Dadhyashira ${ }^{11}$.

According to Sayana Bhashya purpose of adding curd with Soma is to confiscate the Doshas Shukra and Teevra (Shuddha and Tikshna) ${ }^{12}$. Another opinion in this regard is that it enhances the taste of Somarasa ${ }^{13}$. Other than Dadhi, Ksheera and Yava (Barley) were also used as adjuvants which are called as Ashira Dravya $^{14}$. There is reference in Rigveda which states that Ksheera and Dadhi should not be mixed togeth$\mathrm{er}^{15}$.

In Mahabharata, there is a quotation which states that Dadhi is one among the eight exceptions during fast ${ }^{16}$.

\section{DISCUSSION}

Pathya will be decided by considering the Matra (Quantity), Rutu (Season), Samskara (Processing), Desha (Place), Deha (Body), Dosha (Body humor).
Dadhi by its nature is sweetish sour in taste, astringent preceding taste, and heavy to digest, hot in potency, sour in post digestive taste ${ }^{17}$.Here the term Ushna in the quotation applies to both quality and potency ${ }^{18}$. Predominant taste of Dadhi is Amla Svadu and it possesses Grahi and increases Agni and produces Shopha according to AcaryaHarita. The attributes of Dadhi varies according to inoculation time for fermentation, type and nature of milk which is used.

Matra varies based on Guru or Laghu property of the Dravya. Dadhi should not be consumed daily (Nitya Asevana Dravya) ${ }^{19}$, because it's heavy, unctuous and Abhishyandi (increases the secretion), alters the digestion and lead to different ailments ${ }^{20}$. In Ashvini Samhita the time taken for digestion of dadhi is mentioned as "twenty nights", which signifies the heavinessof Dadhi. Hence when Takra (butter milk) prepared by churning Dadhi it will become light. Gastric halfemptying time of the liquid phase was shorter for milk [35 (SE 2) min] than for FM (60 [SE 2) min], which proves that Dadhi is Abhishyandhitama and Guruta$m a$ in comparison to milk.

The goat casein in curd which is both softer and smaller than that produced by cow milk. This makes it more easily accepted by the human digestive system which supports the Laghu and Agni Deepana properties of Aja Dadhi. Fermented goat milk (Lactobacillus RhamnosusCRL1505) demonstrated to stimulate the mucosal immune system and improve the defense against intestinal and respiratory infections in a mouse immunosuppressant model.

These studies support the reference Aja Dadhiis a solution for Svasa, Kasa and Kshaya.

In spring and autumn seasons, Kapha and Pitta will be in aggravated state, so usage of Dadhi is to be restricted, whereas during summer it is restricted due to its hot potency. (Table No -1). Bhojana Kutuhala explains Dadhi as wholesome when consumed in two cold seasons - Hemanta and Sisira ${ }^{21}$. 
Table 1: Dadhi Sevana based on Ritu

\begin{tabular}{|c|c|c|c|c|}
\hline Rutu & Hitahita & Guna & Indication & Adverse \\
\hline Varsha & Hita & - & $\begin{array}{l}\text { ShoSha, vatadi, brama, } \\
\text { Shrama, AtiSara }\end{array}$ & - \\
\hline Greesham & Ahita & $\begin{array}{l}\text { Guru, Amala, Raktapittavrud- } \\
\text { dhi }\end{array}$ & - & $\begin{array}{l}\text { Shopha, Trushna, } \\
\text { Jvara, Vishamajvara }\end{array}$ \\
\hline Hemanta & Hita & $\begin{array}{l}\text { Guru, snigdha, suMadhura, } \\
\text { kaphakrut, balavardhana, } \\
\text { vrushya, medhya, puShti, tushti }\end{array}$ & & \\
\hline ShiShira & Hita & $\begin{array}{l}\text { Vrushya, balakara, Gana, Am- } \\
\text { laMadhura, picchila, guru, } \\
\text { pittakaraka }\end{array}$ & Shramahara & \\
\hline Vasanat & Ahita & $\begin{array}{l}\text { Madhura kincit Amla, snigdha, } \\
\text { vatala, kaphatmakam, ba- } \\
\text { laveerya karaka }\end{array}$ & & \\
\hline Greshma & Ahita & $\begin{array}{l}\text { Amla, atiushna, raktapit- } \\
\text { takaraka, }\end{array}$ & & $\begin{array}{l}\text { Shosha, } \\
\text { pipasa }\end{array}$ \\
\hline
\end{tabular}

Dadhi in Varsha Ritu increases Pitta, Kapha and reduces Vata. It is not advisable to take in diseases like Gulma, Arsha and Kustha. In Greeshmarutu it produces Raktapitta, Vidaha, Shosha, Bhrama and Pipaasa and in Hemanta it causes Shopah, Trishna, Jvara and Vishama Jvara. Also, Acharyas specify that curds should be consumed on alternative days ${ }^{21}$.

In Rutucarya while explaining about the Varsha RutuCharya as it is the Vata Prakopa Kala the Rasa to be consumed in this season is sweet, sour and salt, hence Dadhi can be consumed. VasantaRitubeing Kapha Prakopa Kala, TiktaKatu Kashya Rasas should be consumed and during Sharat being Pitta Prakopa Kala the Rasa Svadhu Tikta Kashaya Rasas can be taken. Also, in both the RitusVata Pitta Prakopa takes place. Being Snigdha, Abhishyandi and Ushna it is not advisable. In Greeshma Rutu though Madhura Rasa is advisable, Dadhi being Ushna Veerya cannot be advised.

Samskara is referred as "Gunantaradhana" - transformation of qualities of Dravya. Heating of Dadhi, is a form of Samskara Virudda (process incompatibility) not advised as it may alter the attributes. Being hot in potency if mixed with hot substances it vitiates Pitta. Dadhi has become a habitual diet now a days. Hence an individual can consume Dadhi either with Mudga Supa (soup of Phaseoius mungo), Madhu (Honey),
Ghrita (Ghee), Sitopala (Sugar candy) or Amalaki (Emblica officinalis). These adjuvants are claimed to counteract the adverse effects of Dadhi.

Dadhi is Satmya to people who live in Jangala Desha and is a Pathya Dravya. Satmya refers to food should not yield accumulation of Dosha, in another way it should give instant strength even after excess usage.

Dravya like Dadhi acts as Samataya Viruddha individual of Anupa Desha people. Curd is unwholesome for the people of low altitude area, as vipareetaguna to place should be considered while selecting the food article. In a Survey conducted at Anupasadharana, which is Kaphapradhana desha observed with in an average $19.8 \%$ of occasional consumers and $22.34 \%$ of daily consumers were showed Kapha Dosha increased symptoms and $10.64 \%$ of occasional and $9.14 \%$ of daily consumers was with Pitta Vruddhi Lakshana respectively. ${ }^{22}$

These adjuvants are claimed to counteract the adverse effects of curd due to vitiated Kapha, Pitta and Rakta. In survey it is evident that ghee, honey and sugar are mixed with curd, whereas Amalaki is used in preparation (fresh or dried Amalaki is grinded with coconut, pepper and Jeeraka then mixed with curd). ${ }^{23} \mathrm{~A}$ study has evidence for good antioxidant activity of mixture of curd and Amalaki. Protein digestibility was more 
when curd is mixed with MudgaYusha (Green Gram Soup) and Ghee. ${ }^{24}$

Table 2: Indications and Contraindications of Dadhi

\begin{tabular}{|l|l|l|l|}
\hline Sl & Disease & Dadhi & \\
\hline no & & Pathya & Apathya \\
\hline 1. & Amavata & - & + \\
\hline 2. & Amlapitta & - & + \\
\hline 3. & Agnimandhya & - & +2 \\
\hline 4. & Arsha & - & + \\
\hline 5. & Aruci & + & - \\
\hline 6. & Atisara & + & - \\
\hline 7. & Bhagandara & - & - \\
\hline 8. & Chardi & + & - \\
\hline 9. & Daham & - & - \\
\hline 10. & Garbhinicarya & +3 & - \\
\hline 11. & Grahani & +1 & - \\
\hline 12. & Gulma & - & + \\
\hline 13. & Hrudrogam & + & - \\
\hline 14. & Jvara & - & + \\
\hline 15. & Kasa & + & +4 \\
\hline 16. & Krimi & - & + \\
\hline 17. & Kustha & - & + \\
\hline 18. & Medoroga & - & - \\
\hline 19. & Mukharoga & - & - \\
\hline 20. & Murca & - & - \\
\hline & & & - \\
\hline
\end{tabular}

Dadhi and by product of Dadhi is Pathya or Apathya in following conditions.

\begin{tabular}{|l|l|l|l|}
\hline 21. & Mutraghata & + & - \\
\hline 22. & Mutrakrucra & + & - \\
\hline 23. & Nasikaroga & + & - \\
\hline 24. & Pandu & - & - \\
\hline 25. & Pittaroga & - & + \\
\hline 26. & Prameha & - & + \\
\hline 27. & Raktapitta & - & + \\
\hline 28. & Shiroroga & - & + \\
\hline 29. & Shopha & - & + \\
\hline 30. & Shuka & - & - \\
\hline 31. & Sula & + & - \\
\hline 32. & Svarabheda & - & + \\
\hline 33. & Trushna & + & +5 \\
\hline 34. & Udara & - & + \\
\hline 35. & Upadamsha & - & - \\
\hline 36. & Urusthambha & - & + \\
\hline 37. & Vatarakta & - & + \\
\hline 38. & Visarpa & - & + \\
\hline 39. & Visha & - & - \\
\hline 40. & Vruddhi & - & + \\
\hline 41. & Yakshma & - & - \\
\hline & & & \\
\hline
\end{tabular}

$1+=$ RukshaDadhi, 2+=Koorcika, 3+=Kilata, Koorcika, 4+= DadhiMastu 5+= DadhiManda

Curd can be Pathya in above diseases sometimes as alone or sometimes mixing with adjutants like sour pomegranate fruit, honey or sugar etc.

Taste enhancing (Rochishnu) and salivation promoting property is appreciated with Dadhi, which is due to acidic taste and sodium and calcium ions. Dadhi is indicated in intermittent fever, where pathogenesis occurs due to- Vata, Kapha or Vatakapha. In-vitro study some evidence claims that certain probiotic strains can inhibit the growth and adhesion of a range of entero pathogens like Salmonella.

In the conditions like Peenasa (Acute and chronic rhinitis) Dadhi by its hot potency does digestion of Ama . In gastrointestinal tract diseases like Atisaara, Grahani and Arshas, Dadhi is useful as an adjuvant and also as one of the ingredients for preparing medicine.
Hypercholestremia due to improper functioning of MedoDhatvagni, Dadhi can be a choice as it influences on Dhatvagni. In preparations of Rasayana it is useful as an ingredient and Anupana. Dadhi also possess property of Vrushya, Taste promoter and flavor for food.

The pathology due toVatadoshaDadhiis useful as Pathya, Anupana and as an ingredient in formulations. Even in AmashayaSamudbhava diseases are also Dadhi is indicated in PakwaAvasta.

In All types of GulmaDadhi is used, because of its Vatahara and Bhruhmana properties. Also, it is useful in Sneha and Kshaara Yoga which are useful in $A g$ nimandhyaja, Annavahasrotas and VataPradhanaVikara. 
While preparing certain Pathya, curd is useful like in Vatajakasa Dadhimastu, VatajaAtisara Dadhidadiman Sadhita Odana is beneficial.

In diet preparation specific to disease Dadhiis used along with adjuvants like Honey, Ghruta and Shakara this establishes the concept "AgrutaSharkaraihi Vina".

\section{CONCLUSION}

Historical Review on Dadhi reveals that from time immemorial curd is a diet. Its usage was popularized when there was need for preserving milk in different forms for obtaining certain therapeutic values which are originally absent in milk. Glimpse over DadhiVarga reveal Dadhi is a component in KheeraVarga. Dadhi can be consumed in daytime without heating by mixing with adjuvants like ghee, sugar etc. occasionally during Varsha, Shishira and Hemanta. Rasa Guna Veerya Vipaka Siddhanta reveals Dadhi by its nature is sweetish sour in taste, astringent preceding taste, heavy to digest, hot in potency, sour in post digestive taste. Dadhi is Satmya to people who live in Jangala Desha and is a Pathya Dravya. Concept of Viruddha reveals Dravya like DadhiKsheera acts as Viruddha even by Samaana Guna as in Anupa Desha people consuming Dadhi.

\section{REFERENCES}

1. $\mathrm{T} \mathrm{V}$ kapalishastry commentary on rig veda, rigvedasamhita 8/73/1.

2. Devi chand, munshiram manoharlal, the Yajurveda 18/12, Hindu literature samskrit 1998.

3. K bloom field, The Atharveda Shastha kanda 2/140, strassburg, veralag von karl j truner 1890

4. Kashyap, Amlapitta Chikitsaadhyay, editor Prof. P.V.Tiwari, Kashyap Samhita, 1st edition, Varansi, Chaukhamba Vishvabharti, 1996, page- 468.

5. Harit, Aushadha Parigyan Vidhan, TrityaSthan, editor HariharaPrashadTipathi, Chaukhambha Krishnadas Academy, Varanasi, 2005, page- 173.

6. Anonymous, Jwarchikitsa, Yogaratnakara, editor P.V. Tiwari, Ist edition, Chaukhambha Vishvabharti, Varanasi, 2010, page- 286

7. Lolimbaraja, Prathamo Vilasa, Vaidya Jeevana, editor Priyavrat Sharma, Chaukhambha Surbharti Prakashan, Varanasi, 2013, page- 6 .
8. Sushrutha, sushruthasamhita, Nibandhasangraha, commentary by Dalhanaacharya reprint chikitsastana [5/12], Chaukhambha Surbharati Prakashan, Varanasi; 2017.

9. Sushrutha, sushruthasamhita, Nibandhasangraha, commentary by Dalhanaacharya reprint chikitsastana [25/38], Chaukhambha Surbharati Prakashan, Varanasi; 2017

10. Wright T, Singh R. Dairy and Products Annual, Cited on [18 Jan 2013]. Available from; http://static.globaltrade.net/files/pdf/201102262312556 27.pdf.

11. Acharya YT, CarakaSamhita of Agnivesga. $5^{\text {th }}$ ed. Varanasi: Choukhambha Surabharati Prakashana; reprint 2007, p.P133.

12. Acharya YT, Sushruta Samhita of Sushruta. $5^{\text {th }}$ ed. Varanasi: Choukhambha Surabharati Prakashana; reprint 2003, p.202.

13. Acharya YT, Caraka Samhita of Agnivesga. $5^{\text {th }}$ ed. Varanasi: Choukhambha Surabharati Prakashana; reprint 2007, p. P60.

14. Arya RP, Joshi KL. Rgveda Samhita Sanskrit text english notes tanslation by $\mathrm{HH}$ Wilson \& Bhashya of Sayanacarya: Vol 2; Mandalas. Delhi; Parimal publication, $2^{\text {nd }}$ revised edition 2001, p.355.

15. Arya RP, Joshi KL. Rgveda Samhita Sanskrit text english notes translation by $\mathrm{HH}$ Wilson \& Bhashya of Sayanacarya: Vol 2; Mandalas. Delhi; Parimal publication, $2^{\text {nd }}$ revised edition 2001, p.471.

16. Arya RP, Joshi KL. Rgveda Samhita Sanskrit text english notes tanslation by $\mathrm{HH}$ Wilson \&Bhashya of Sayanacarya: Vol 2; Mandalas. Delhi; Parimal publication, $2^{\text {nd }}$ revised edition 2001, p. 12 .

17. Acharya YT, Sushruta Samhita of Sushruta. $5^{\text {th }}$ ed. Varanasi: Choukhambha Surabharati Prakashana; reprint 2003, p.202.

18. Acharya YT, Commentary by Dalhana on Sushruta Samhita of Sushruta. $5^{\text {th }}$ ed. Varanasi: Choukhambha Surabharati Prakashana; reprint 2003, p.202.

19. Acharya YT, Caraka Samhita of Agnivesga. $5^{\text {th }}$ ed. Varanasi: Choukhambha Surabharati Prakashana; reprint 2007, p.38.

20. Acharya YT, Caraka Samhita of Agnivesga. $5^{\text {th }}$ ed. Varanasi: Choukhambha Surabharati Prakashana; reprint 2007, p.106

21. Raghunatha Suri, Bhojanakutuhalam, ed. Scholars of the center for theoretical foundation, I- AIM, Bangalore; Centre for theoretical foundation, I- AIM, ed. p.345 
22. Priyanka B.V. AND Manjunatha Adiga. The Concept Satmya Vis A Vis Curd Consumption - A Cross Sectional Case Series Study. International Ayurvedic Medical Journal \{online\} 2020 \{cited April, 2020\} Available from:

http://www.iamj.in/posts/images/upload/3434_3437.pd f.

23. Priyanka B.V. Mallika Kurat Jayavarma. Dietic practice of curd - demographic survey. Ayurpharm Int J Ayur Alli Sci., Vol.2, No.12 (2013) Pages 364 - 371.

24. Dr Abhijit H Joshi, Dr Manoja Abhijit Joshi. The study of antioxidant activity of cow curd and itys combination with various food articles. IJREHS, Vol.2, No.1 (2019) Pages 32-37.

\section{Source of Support: Nil}

\section{Conflict of Interest: None Declared}

How to cite this URL: Priyanka B.V et al: Concept Of Pathya And Apathya With Special Reference To Curd - A Review. International Ayurvedic Medical Journal \{online\} 2021 \{cited May, 2021$\}$ Available from: http://www.iamj.in/posts/images/upload/1101_1107.pdf 